\title{
風化度に着目した乱さないまさ土の圧縮・せん断特性
}

\section{COMPRESSIVE AND SHEAR CHARACTERISTICS OF UNDISTURBED DECOMPOSED GRANITE SOILS PAYING ATTENTION TO THE DEGREES OF WEATHERING}

\author{
村田秀一*. 兵動 正幸**. 安福規之*** \\ By Hidekazu MURATA, Masayuki HYODO and Noriyuki YASUFUKU
}

\begin{abstract}
In order to investigate the compressive and shear characteristics of undisturbed Hiroshima type decomposed granite soils, the isotropic compression and triaxial compression tests were carried out using the undisturbed specimens made up by the new core bit. Test results were discussed paying attention to the degrees of weathering of samples.

The results obtained can be summaraized as follows.

1) The irreversible change of void ratio under isotropic compression is due to the particle breakage and the vanishing of structure effect.

2) The stress-strain behavior, stress-dilatancy relation and shear constant $\phi^{\prime}$ depend on the degrees of weathering.

3) Failure criterion is expressed in terms of coefficient of the exponent.

4) The decrease in strength due to submergence is remarkable in a low confining pressure and in moderately weathered sample.

Keywords: particle breakage, stress-strain curve, triaxial compression test, undisturbed decomposed granite soil, weathering
\end{abstract}

\section{1. まえがき}

代表的な風化残積土であるまさ土は広く西日本に分布 し, 盛土材料として比較的よく利用され, その力学的特 性についてもかなり研究がなされている，一方，近年ま さ土地帯の土工を伴う地域開発や防災対策に関連して, 地山のまさ土の工学的な性質を詳細に解明する必要にせ まられている。しかしながら，まさ土の乱さない供試体 の作成がきわめて困難であること，土粒子がもろく，ま た風化の程度によって力学的性質が大きく異なることな ビのため, 乱さないまさ土の工学的性質に関する研究は 遅れている.

最近になって，豪雨のたびに斜面崩壊を引き起こすま さ土地帯における乱さないまさ土試料の採取法, 供試体 の作成方法, 工学的なまさ土の分類方法や三軸圧縮試験 による力学試験結果が, 吉中, 小野寺 ${ }^{1)}$, 柴田, 清水,

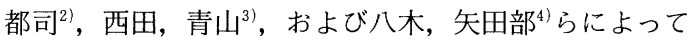
報告され，その工学的性質についてしだいに明らかにさ

\footnotetext{
* 正会員 工博 山口大学教授 工学部建設工学科 （拎55 宇部市常盤台 2557）

** 正会員 工博 山口大学講師 工学部建設工学科 (同上)

*** 正会員 工修 山口大学助手 工学部建設工学科 (同上)
}

れつつある.しかし，まさ土の風化の程度に関連づけて， 乱さないまさ土の工学的性質の定量的な解釈がなされた ことは, 基本的問題であるにもかかわらず，ないようで ある. まさ土は，分布する場所において多種多椂の物理 および工学的性質を示し，必ずしも同じ方法で乱さない 試料の採取および供試体の作成が可能とは限らない，著 者らは, 三軸試験用の乱さない円筒形供試体の作成方法 を確立して以来，西中国地方に分布し，比較的粗粒分を 多く含んでいることで知られている広島型花崗岩の風化 した乱さないまさ土の工学的性質について検討してき $t^{5\rangle, 6)}$.

本研究は, 西中国地方に分布する 10 数種のインタク 卜な乱さない広島型まさ土供試体に対し，三軸圧縮試験 を 30〜 400 kPa の拘束圧下で実施し，その圧縮・せん 断特性を風化度に着目して考察したものである。

\section{2. 乱さないまさ土供試体の作成方法}

乱さないまさ土を地山から採取するには，ブロックサ ンプリングのほか, 釘打込み法が西田, 青山によって提 案され実績を挙げている7゙.また，採取された試料から， 三軸試験用円筒形供試体を得るため, 西田, 青山常は, トリマーを用いた供試体作成方法も提案している。この 


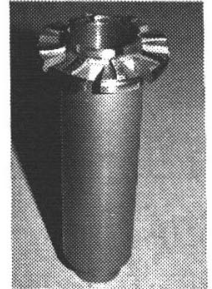

Photo 1 Core bit

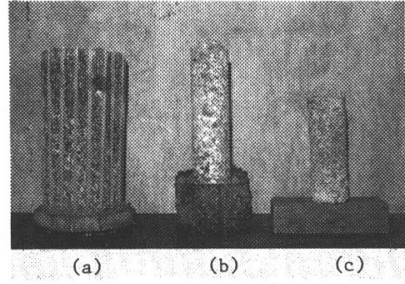

Photo2 Undisturbed specimen.
方法は近畿地方に主として分布する領家型花崗岩の風化 したまさ土に対して適用可能と思われ，西中国に分布す る比較的粗粒な広島型まさ土に対しては適用できなかっ た。 そこで，著者らは，今回供試体の作成過程で武料を 凍結する方法を採用した。しかしながら凍結した試料に 対して, 通常の岩石用のコアビットを用いただけでは, 三軸用供試体を作成することは不可能であった。このた め, 著者らはPhoto 1 に示すようなコアビットを新たに 考案し，それを三軸供試体の作成に供した。なお，本論 文は乱さない供試体の作成方法を述べることを主目的に していないので，以下凍結した試料から乱さない供試体 を作成する方法については簡単に述べる. 考案したコア ビットの特徵は，回転中試料の削粉を直接周囲に飛ばす 目的でコアビット側面にダイヤチップ付きのフランジ部 を設けていること，およびコアビット内部に発生する摩 擦熱を低減させるためにコアビットの内径をコアビット 先端部より $1 \mathrm{~mm}$ 大きくしたことにある.さらに, 回転 中にコアビット上端より窒素ガスを噴出させ，供試体を 低温に保つと同時に窒素ガス圧によって削粉を排除する ように工夫した．乱さないまさ土供試体（直径 $50 \mathrm{~mm}$, 高さ $125 \mathrm{~mm}$ ) の作成手順を以下に示す.

（1）不連続面の介在しない地山を選び，表土を削土 しベンチカットする。

（2）釘打込み法によって，直径約 $100 \mathrm{~mm}$, 高さ $220 \mathrm{~mm}$ の円筒形試料を採取する (Photo 2 (a)).
（3）釘とテープで拘束された試料をコンテナに入 れ，慎重に運搬する。

（4）釘とテープで拘束した自然含水状態の試料をビ ニール袋に包み, $-20^{\circ} \mathrm{C}$ の冷凍庫内で 24 時間凍結する.

（5）凍結試料を各種のデバイスを用いて，ボーリン グマシン（精研ダイヤモンド工業, SBR-2）に固定し, $720 \mathrm{rpm}$ で回転するコアビットで削り, 逆 T 型供武体を 得る (Photo 2(b)). 試料の削り出しに要する時間は, 試料によって若干異なるが約 7 10 分である.この間, 試料とコアビットの間に削粉が入り込むのを防ぐため に, コアビット上方上り約 $-60^{\circ} \mathrm{C}$ の窒素ガスを約 80 $\mathrm{kPa}$ の圧力で送り続ける.

（6）逆 T 型試料の上下面をディスクカッターで切 断し, 直径 $50 \mathrm{~mm}$, 高さ $125 \mathrm{~mm}$ の供試体を作成する (Photo2 (c)).

このようにして作成された乱さない供試体を用いて， 凍結が供試体の乱札に及ぼす影響を検討したが，その影 響はほとんどないことを確かめている81,9)。また，乱さ ない試料を凍結した後，特殊なコアビットを用いて円筒 形供武体を作成する方法は，八木らによっても提案され ている4),10)．著者らの試作したコアビットは，八木らの 試作したコアビットと，原理的には同じであるが，著者 らの方法を用いると, 自然含水状態の供試体を作成する ことが可能である.

\section{3. 風化度の判定指標}

まさ土は, 鉱物組成や風化の程度が場所によって著し く異なりその工学的性質が複雑な土として知られてい る. したがって, 風化の程度を判定できる指標を定めて おくことは, このような材料を取り扱ううえで大変便利 である. まさ土の風化過程では，脆弱な長石や雲母は急 速に粘土化されるが，石英は風化に対して抵抗性が強い といわれている ${ }^{11)}$. そこで，風化の指標として，(1) 長石比重,（2）見掛け比重,（3）比表面積,（4）強

Table 1 Index properties of undisturbed samples tested.

\begin{tabular}{|c|c|c|c|c|c|c|c|c|c|c|c|}
\hline No & 探取地 & $\begin{array}{c}\text { 比重 } \\
\text { Gs }\end{array}$ & 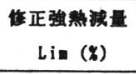 & $\begin{array}{r}\text { 強刦娍量 } \\
\text { Li }(\%)\end{array}$ & $\begin{array}{c}\text { 間隐比 } \\
\mathrm{e}\end{array}$ & 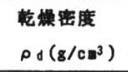 & $\begin{array}{c}\text { 自然含水比 } \\
\text { Wn (\%) }\end{array}$ & $\begin{array}{l}\text { 吸水率 } \\
\text { Ab (x) }\end{array}$ & $\begin{array}{l}\text { 祭和含水比 } \\
\text { Wsat (x) }\end{array}$ & $\begin{array}{l}\text { 柆度分布 } \\
\text { 新. 粘土分 }\end{array}$ & (\%) \\
\hline 1 & 広島累 & 2.866 & 0.84 & 1.68 & - & - & - & 2.34 & - & - & - \\
\hline 2 & 山口罴 & 2.702 & 0.97 & 2.97 & - & - & - & 3.90 & - & 7.9 & 55.4 \\
\hline 3 & 厸島悬 & 2.887 & 1.17 & 2.25 & - & - & - & 2.78 & - & 8.7 & 65.2 \\
\hline 4 & 山口䋰 & 2.817 & 1.37 & 3.92 & $0.428-0.508$ & $1.741-1.833$ & $6.1-11.1$ & - & $16.4-18.2$ & 19.2 & 81.? \\
\hline 5 & 山口眻 & 2.811 & 2.19 & 4.29 & $0.443-0.514$ & $1.725-1.808$ & $8.9-10.0$ & - & $17.0-18.7$ & 12.3 & 58.7 \\
\hline 6 & 山口囪 & 2.618 & 2.90 & 5.58 & $0.603-0.732$ & $1.500-1.620$ & $8.2-13.4$ & 5.81 & $23.0-28.0$ & - & - \\
\hline 7 & 厷島県 & 2.610 & 3.18 & 5.88 & $0.525-0.851$ & $1.440-1.748$ & $12.7-21.1$ & 5.56 & $20.1-32.6$ & 15.0 & 60.6 \\
\hline 8 & 山口畏 & 2.618 & 3.81 & 8.02 & $0.752-0.830$ & $1.428-1.493$ & $17.7-19.5$ & - & $28.8-31.7$ & - & - \\
\hline 9 & 山口曼 & 2.830 & 3.91 & 9.16 & $0.770-0.792$ & $1.468-1.488$ & $17.8-18.7$ & - & $29.3-30.1$ & 16.5 & 52.2 \\
\hline 10 & 山口累 & 2.623 & 4.04 & 6.81 & $0.888-0.892$ & $1.388-1.574$ & $11.4-18.3$ & 6.98 & $25.4-34.0$ & 19.5 & 72.9 \\
\hline 11 & 山口息 & 2.829 & 4.50 & 7.67 & 0.678 & 1.487 & $18.1-16.4$ & - & 29.2 & 18.3 & 69.1 \\
\hline 12 & 山口貫 & 2.630 & 4.99 & 8.80 & $0.918-1.105$ & $1.280-1.372$ & $20.7-28.8$ & 8.04 & $34.8-40.1$ & 26.2 & 63.8 \\
\hline
\end{tabular}


熱减量, (5) 吸水率, (6) $\mathrm{pF}$ 值,（7) 間隙比，（8） 有色鉱物含有量などが用いられている(2),13)。 また，風化 試料の非晶物質を定量し，それを風化度と関係づけてい る例もみられる14).

そこで, 本研究で用いた Table 1 の試料を対象に, 上 記した各指標およびその相互の関連性について調べてみ た. Fig. 1 は, 比較的簡単に得られる各指標之まさ土の 結晶水や吸着水の含有量を表わす修正強熱減量との関係 を示したものである．なお，土質工学会基準による強熱 減量 $L_{i}$ は, 原試料の中から $0.42 \mathrm{~mm}$ 以下の試料 $2 \mathrm{~g}$ を 取り出して測定されるため(強熱時間 2 3 時間)，この 量 $L_{i}$ は結果的に粒径が $420 \mu \mathrm{m}$ 以下の試料の風化度を 判定していることになる。しかし，ここで扱っているま さ土試料には $420 \mu \mathrm{m}$ ふるいい通らない粗粒な土粒子が 多く含まれており, 従来の強熱減量 $L_{i}$ では, これらの まさ土の風化度を判定することは難しい。したがって本 研究では, 現場から採取した原試料の中から $5 \mathrm{~g}$ を取り 出して強熱減量を測定し(強熱時間 5 6 時間), これを 修正強熱減量 $L_{i m}$ と称し, この量をもって原試料の風 化度の判定を行っている．ここで $5 \mathrm{~g}$ を取り出す明確な 理由はないが, $5 \mathrm{~g}$ 程度とれば $L_{i m}$ に測定のばらつきは 少なくなると考えた. Table 1 に示した修正強熱減量の 值は, 各試料 6 個の值の平均值であるが, 各測定值にば らつきはほとんよ゙なかった. Fig.1より土粒子の比重 や粘土含有量は主として母岩の性質に支配されているた め, 修正強熱減量との相関性がさほざみられないが, 吸 水率, 間隙比, 乾燥密度および飽和時含水比はいずれも 修正強熱減量と相関性がよいことがわかる，ところで， 間隙比, 乾燥密度および飽和時含水比は, 乱さない武料 を採取するかあるいは原位置での密度の測定をしなけれ ば得られない。しかし，これらの作業は容易なことでは なく，ばらつきも大きい，そこで，本論文ではまさ土の 風化度を表わす指標として, 簡単に求められ，かつ測定 誤差も少なく，また後述するように力学的性質との対応
性も優れている修正強熱减量を用いることにした。なお， Table 1 の試料番号は新鮮な試料から風化の進んでいる 試料順に付してある。

\section{4. 試験方法}

風化度に着目して, 自然含水状態の乱さないまさ土の 圧縮・せん断特性を調べるため，七ル内に満たした側液 の増減で供試体の体積変化が測定可能な不飽和土用三軸 圧縮試験機を用いて実験を行った。凍結している供試体 は, 脱気水で満たされたセル内で 12 時間放置され，十 分融解した後試験に供される.

等方圧縮試験では, 各荷重段階の圧縮終了の基準を体 積圧縮変化量が $0.1 \mathrm{~cm}^{3} / \mathrm{h}$ となったときとした．また， 三軸圧縮試験は，圧密排水（気）条件下でひずみ制御方 式とし，拘束圧一定のもとでひずみ速度 $0.15 \% / \mathrm{min}$ で 行われた。なお，このひずみ速度でせん断した結果は, ひずみ速度 $0.02 \% / \mathrm{min}$ でせん断した場合の結果と同じ であることを確かめている.

また, 乱さない供試体と乱した供試体の応力・変形特 性を比較するため, 乱した試料についても同様の試験を 実施した。この場合，乱した供試体は，自然含水状態で 乱さない試料の間隙比と同一になるように締固めて作成 されたものである.さらに，乱さない供試体の浸水によ る強度・変形特性の変化を調べるために, おのおのの試 料の飽和供試体を用いて三軸圧縮試験を行った。一般に, 乱さないまさ土の飽和は, 試料の風化の程度によっては 困難と考えられているが，今回炭酸ガスと背圧を併用し て飽和度を高める工夫をした。炭酸ガスの通気時間 15 分 (通気圧 $5 \mathrm{kPa}$ ), および背圧 $100 \mathrm{kPa}$ を供試体に負 荷することによってすべての供試体の $B$ 値は 0.96 以上 であった。

\section{5. 乱さないまさ土の等方圧縮特性}

Fig. 2 は，風化度の異なる自然含水状態の乱さないま
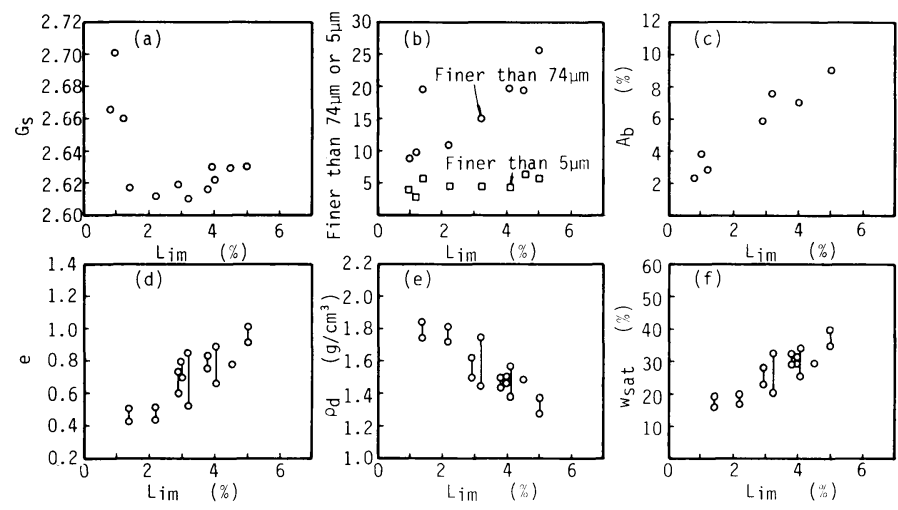

Fig. 1 Correlations among physical and chemical properties of undisturbed samples. 
さ土 (No. 5, 8) の $e-\log p_{i}$ 関係を示したものである この図より, 乱さないまさ土の初期載荷曲線には, 除荷 曲線に似た勾配をもつ直線部分と(ここでは初期載荷圧 縮曲線とよぶ），正規圧縮曲線に対応するような直線部 分 (正規圧縮曲線とよぶ) が存在していることがわかる. しかし, 初期載荷圧縮線から正規圧縮線に移行する応力 点 (圧縮降伏応力) は明瞭には現われていない. そこで, この応力を Fig. 2 に示すように, $p_{y 1}, p_{y_{2}}$ の 2 つの応力 で代表させ, 以下若干の考察を行った。

Fig. 3 に, 圧縮指数 $C_{c}$, 膨張指数 $C_{s}$ および $p_{y 1}, p_{y 2}$ と風化度 $L_{i m}$ の関係を示した. 乱さないまさ土の $C_{c}$ の 値は 0.1 0.5 となり, $C_{c}$ は $L_{i m}$ の増大に伴って増加し, $p_{y_{2}}$ は $L_{i m}$ の増大に伴って低下するが， $C_{s}$ 之 $p_{y_{1}}$ は風化 度依存性がそれほどみられない，このことは, 乱さない まさ土の等方圧縮応力の増加に伴う間隙比変化に占める 塑性変形の割合が風化の進んだ試料ほど大きくなること を示している，さらに，圧縮特性の風化度依存性は，塑 性変形成分に対してであり，この図を見みるかぎり弾性 成分にはほとんど反映されないことがわかる．等方圧縮 応力下でのまさ土の粒子破砕特性を検討するため, 2 種 性変形成分に対してであり，この図をみるかぎり弾性成 分にはほとんど反映されないことがわかる．等方圧縮応 力下でのまさ土の粒子破研特性を検討するため， 2 種類 の乱したまさ土 (No.2，7）を用い，気乾状態と飽和状 態において $20 \mathrm{MPa}$ までの等方圧縮試験を行った ${ }^{15)}$. 本 研究では, 粒子破砕を数量化する尺度として次式で示さ れる表面積増加量 $\Delta S^{16), 17)}$ を用いた。
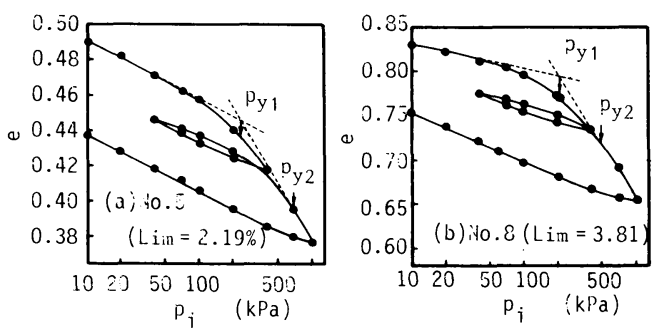

Fig. $2 e-\log p_{i}$ curves of undisturbed specimen.
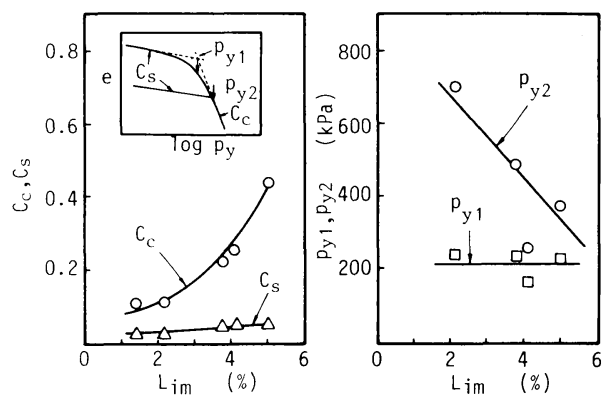

Fig. 3 Relation between $C_{c}, C_{s}, p_{y_{1}}, p_{y_{2}}$ and $L_{i m}$

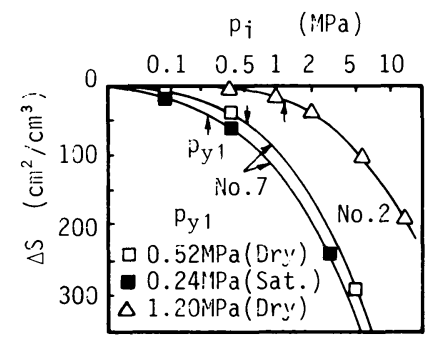

Fig. $4 \Delta S$ - $\log p_{i}$ curves of disturbed specimens.

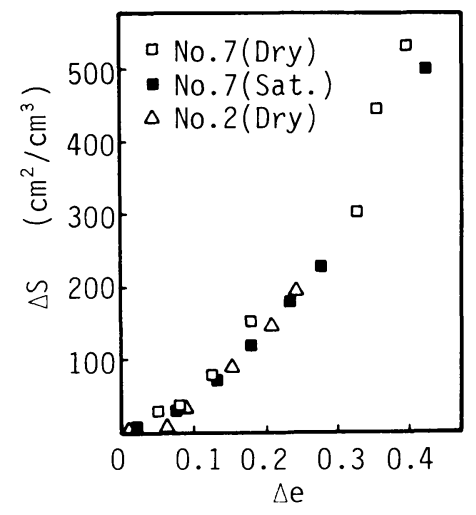

Fig. 5 Relation between $\Delta S$ and $\Delta e$ of disturbed specimens.

の単位体積当たりの表面積である.なお，測定方法は三 浦，山内が提案した方法を用いている17).

乱した試料における $e-\log p_{t}$ 曲線の形状は，乱さな い試料の結果と定性的には同じである。そこで，等方圧 縮過程における $\Delta S$ と $p_{i}$ との関係を整理すると, Fig. 4 のようになった．図中には圧密降伏応力に相当する $p_{y 1}$ の值も示しているが, この值と $\Delta S$ が顥著に増加し始 める応力とが比較的よい対応を示している．また， $\Delta S-\log p_{i}$ 曲線の形状は $e-\log p_{i}$ 曲線の形状と類似し ており，まさ土の正規圧縮に対応する領域では破砕が急 速に進行することを裏付けるものである．したがって， この結果に基づけば，まさ土の正規圧縮領域に対応する 領域は粒子破砕が顥著に生じる応力域すなわち粒子破砕 領域と考えてよさそうである。このような特性は，砂や 砅においてもみられることを実験的に調べているが18), 風化がある程度進んだまさ土の場合は，この現象が特に 顥著であるといえる．また，粒子破砕量は水が加わるこ とによって多少ではあるが，促進されることも Fig. 4 か らわかる.

Fig. 5 は, No. 2, 7 試料の $e-\log p_{i}$ 曲線と Fig. 4 で 示した $\Delta S-\log p_{i}$ 曲線を用いて描いた等方圧縮過程に おける間隙比変化 $\Delta e$ 之表面積増加量 $\Delta S$ (粒子破砕量 と考えてよい）の関係を示している．この図は，風化度 や含水状態にかかわらず $\Delta S$ と $\Delta e$ の間には一義的な関 
係が存在することを示している。これはここで調べた さほよ゙風化の進んでいない新鮮なまさ土においては, そ の間隙比変化が，主に粒子破砕によって規定されている ことを示唆するものであり大変興味深い. もっとも, 乱 さないまさ土では, 間隙比変化の要因として, このほか に粒子破砕に起因しない乱さないまさ土特有の構造効果 の消失が存在すると考えることは，想像に難くない．

\section{6. 乱さないまさ土の応力変形特性}

\section{（1）応力・ひずみ挙動と風化度の関係}

Fig. $6(\mathrm{a}) \sim(\mathrm{d})$ は，おのおの風化度の異なる乱さな いまさ土の三軸圧縮試験における応力・ひずみ関係であ る. 風化の進んでいない比較的新鮮な試料 (No.4, 5) は， $\sigma_{3} \leqq 400 \mathrm{kPa}$ においては典型的なひずみ硬化軟化型 挙動を示し, 体積ひずみも著しい膨張が生じている。こ れに対し, 比較的風化の進んだ試料 (No.8，12) は, ひずみ硬化型挙動を示し，体積ひずみは低い拘束圧下で は膨張を示すものの, 拘束圧の増大とともに収縮の傾向 が強まっている.

応力・ひずみ挙動の風化度依存性をより明確にするた め, 同一拘束圧下 $\left(\sigma_{3}=30 \mathrm{kPa}\right)$ における風化度の異な る乱さない試料の応力・ひずみ曲線を比較したのが,

Fig.7(a) である. また, Fig.7（b) に，乱した試料の 試験結果も比較のために示した. 乱さない試料に関して は, 応力レベルの低い部分で軸差応力 $q$, 体積ひずみ $v$ ともに風化度の違いによる差はほとんどみられない. しか

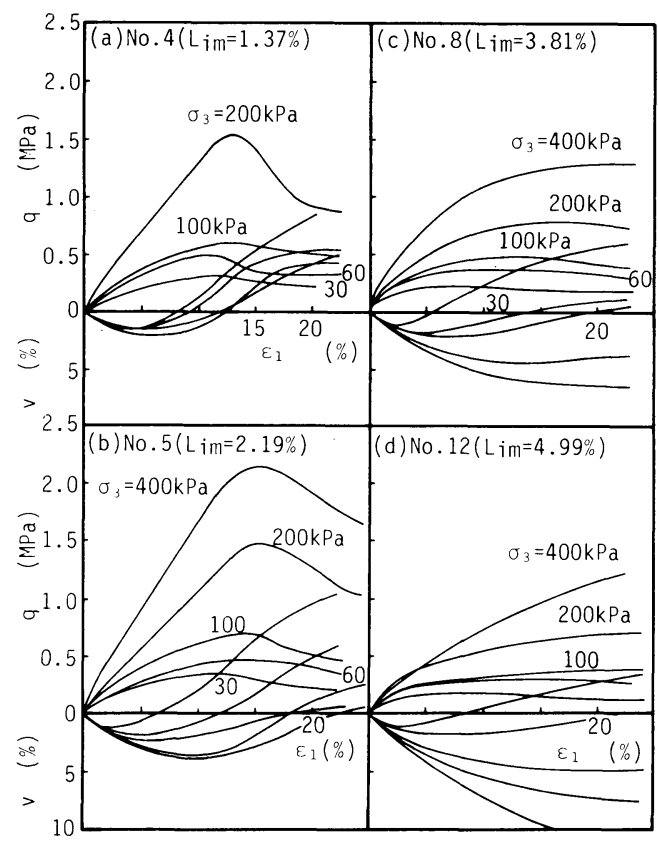

Fig. 6 Triaxial compression test results of undisturbed specimens.

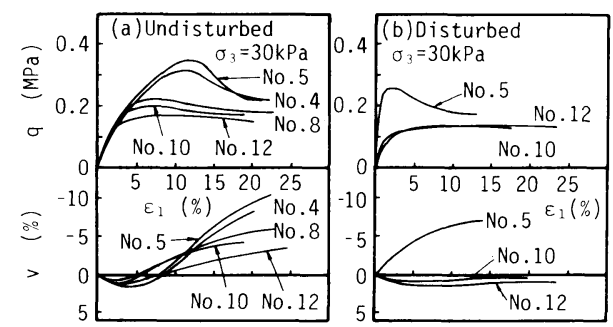

Fig. 7 Comparison of stress-strain curves on undisturbed and undisturbed specimens.

し，軸ひずみの進行に伴い，それらに相違が明瞭に現わ れてくる. $q$ に関しては, 全試料ともピーク值が存在し, その值は同じ拘束圧下で比較した場合には, 風化度の低 いものほど高い。また，ピーク強度後の軸ひずみ $\varepsilon_{1}$ の 進行に伴う軟化現象は, 風化度の低いものほど著しい. $v$ に関しては, 軸ひずみの小さい所で全試料とも体積収 縮を示すが, $\varepsilon_{1}=3 \%$ 付近から体積膨張に転じ, 風化度 の低いものほよ゙ $\varepsilon_{1}$ の進行に伴う体積膨張は著しい。 ま た, 乱さないまさ土の場合, せん断初期の体積収縮量が 必ずしも風化の進んだ式料のほうが大きくなるというわ けでもなく, $30 \mathrm{kPa}$ の拘束圧下では, 比較的新鮮な No. 4, 5 の試料の方が, No. 10, 12 といった風化の進 んだ試料に比べて最大の体積収縮量は大きいという結果 になっている.

一方, 同一試料に着目して, 乱さないまさ土と乱した まさ土の応力・ひずみ関係を比較すると, 次のようなこ とがいえる. 乱さないまさ土の $q-\varepsilon_{1}$ 関係の初期の立上 がりは，乱したまさ土のそれに比べてかなり緩やかであ るにもかかわらず, 最大軸差応力 $q$ は, 大きな值を示す. また，そのときの軸ひずみ量も大きい，さらに， $v^{-} \varepsilon_{1}$ 関係において, $\varepsilon_{1}$ の増大に伴う体積膨張の割合が, 乱 さないまさ土の場合，かなり大きい，同様の結果は，八 木ら 文によっても報告されている。このような特性の違 いは，風化度の低い試料ほど明瞭に現われており，かつ せん断時の拘束圧が低いほど䫓著である。これは，乱さ ないまさ土と乱したまさ土の組織構造や粒子破䂶特性の 相違に起因しているところが大きいと考える.すなわち, 乱さないまさ土の場合, 風化過程で母岩が有していた固 結力は失われていくものの, 間隙の大きさが, 締固めた まさ土に比べて相対的に大きく ${ }^{4)}$ ，またそれらが均質に 存在しないといった乱さないまさ土特有の不安定な組織 構造が残存しているのに対し，乱したまさ土では，たと え同一の密度で締固めたとしても，上述のような構造を 再現することができない。 さらに，乱したまさ土では， 締固めの際，すでに脆弱な粒子はかなり破砕しており， 特に低い応力域を考えた場合には次節で述べるように圧 縮・せん断過程における粒子破砕特性が, 乱さないまさ 


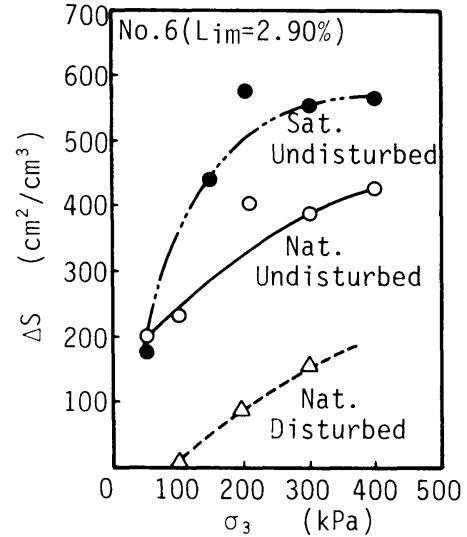

Fig. 8 Increase of surface area $\Delta S$ in triaxial compression tests.

土のそれに比べて著しく異なったものである．このよう な，構造および粒子破砕特性の違いが，特に低応力下で の強度特性やストレス・ダイレイタンシー特性の違いと して現われているものと考える.

\section{（2）粒子破䂶特性}

乱さないまさ土のせん断中の粒子破砕特性を表面積増 加量により調べるには，その原試料となるものの規定が 非常に困難であるため, 定量的に破砕特性を把握するこ とは難しい。ここでは, 圧縮・せん断過程における表面 積増加量を式（1）を用いて求めた。なお, 式（1）に おける $S_{0}$ を求めるにあたり基準となる原試料を土質試 験法によって規定されているまさ土の粒度調整方法 ${ }^{19)} に$ 従ってほぐした試料とした。
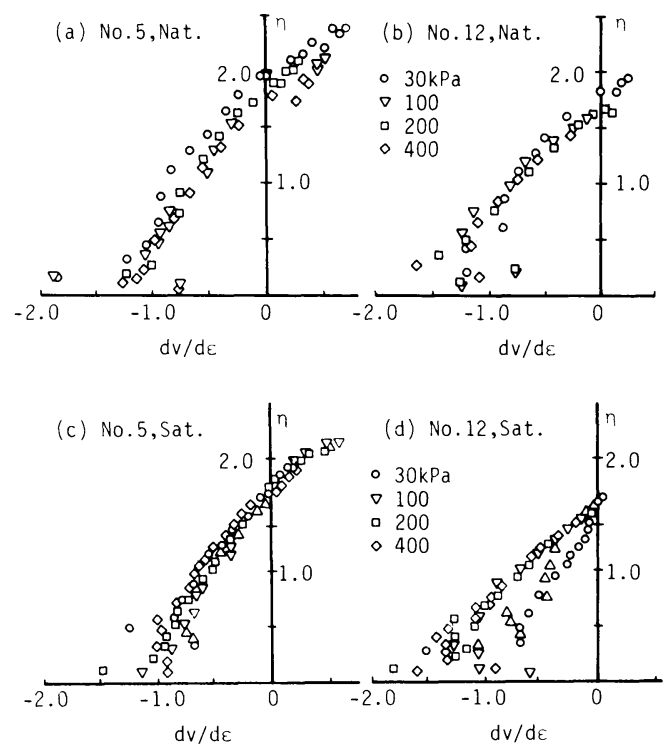

Fig. 9 Relation between $\eta$ and $(d v / d \varepsilon)$ of undisturbed specimens.
Fig. 8 はその結果である.この図より，まず前節で述 べたようにまさ土は比較的低い応力域において粒子破砕 が生じること, また乱さない試料が締固めた試料より粒 子破砕量が多いこと, 特に乱した試料では $\sigma_{3}<100 \mathrm{kPa}$ では粒子破砕が生じていないことがわかる.さらに，自 然含水状態の試料より飽和試料のほうが粒子破砕が生じ やすいことも示している.なお，このような粒子破砕特 性は，他のまさ土にも定性的にはいえることであると考 えられる.

\section{（3） ストレス・ダイレイタンシー関係}

Fig. $9(\mathrm{a})$ (d) は, 風化度のかなり異なる試料 (No. 5, 12）の自然含水状態および飽和状態の三軸圧縮試験結果 を, 応力比 $\eta$ とひずみ増分比 $(d v / d \varepsilon)$ の関係で整理し たものである.ここで, せん断ひずみ $\varepsilon$ は $\varepsilon_{2}=\varepsilon_{3}$ を仮定 して, $\varepsilon=2\left(\varepsilon_{1}-\varepsilon_{3}\right) / 3$ として求めている. これらの図 より, 含水状態および風化度によらず, また $\eta$ の低い 所を除けば拘束圧に関係なく，おおむね $\eta$ と $(d v / d \varepsilon)$ の間には，次式で示すような直線関係が認められる.

$$
d v / d \varepsilon=\alpha(M-\eta) \cdot
$$

ここで, $M$ は $d v / d \varepsilon=0$, すなわちせん断過程にお いて体積ひずみが, 収縮から膨張に転ずる応力比であり, $\alpha$ は, $\eta-(d v / d \varepsilon)$ 直線関係の勾配の逆数である.この

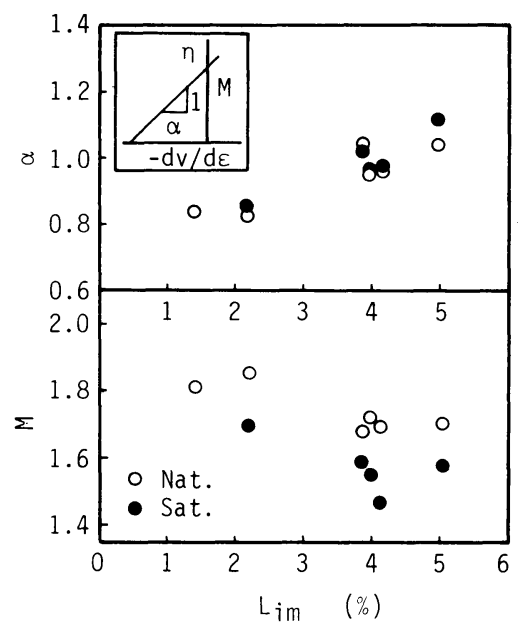

Fig. 10 Relation between constants $\alpha, M$ and $L_{i m}$.

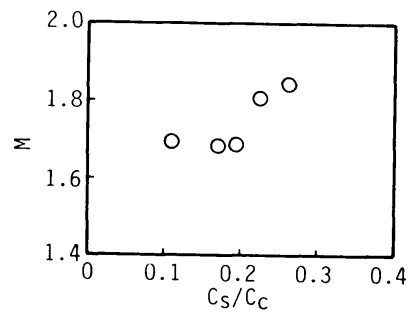

Fig. 11 Relation between $M$ and $C_{s} / C_{c}$. 


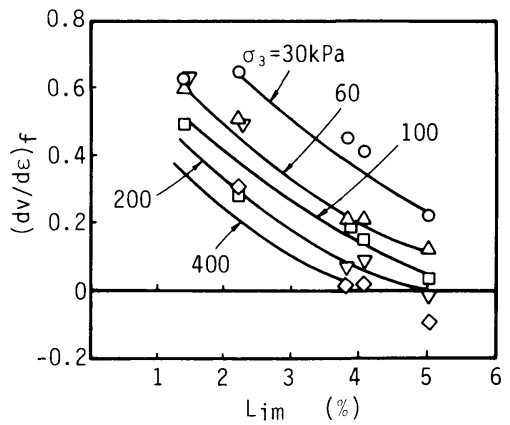

Fig. 12 Relation between $(d v / d \varepsilon)_{f}$ and $L_{i m}$.

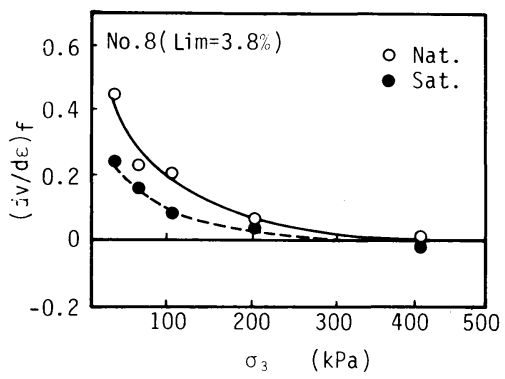

Fig. 13 Relation between $(d v / d \varepsilon)_{\mathcal{s}}$ and $\sigma_{3}$.

ような関係は, 乱さないしらすにおいてもみられること が春山，北村によって報告されている20)

ところで, $\eta$ の低い所で $\eta-(d v / d \varepsilon)$ 関係が式 (2) からはずれ，過圧密砂や過圧密粘土で一般によくみられ るように, 若干右方向に移動しているが, この理由の 1 つとして次のことが考えられる.すなわち，Fig. 2 の $e-\log p_{i}$ 関係から判断されるように, せん断時の拘束 圧が $p_{y 1}$ 值より低い場合には，乱さないまさ土の応力状 態は少なくとも圧縮過程においては，いわゆる過圧密的 であり，その影響が Fig. 9 に示すようにせん断初期のス トレス・ダイレイタンシー特性に現われているものと考 える.Fig. 10 は, 式 (2) の実験定数 $\alpha$ と $M$ の風化度 依存性, および含水比変動がそれらの定数に及ぼす影響 を調べたものである.ここで示した $\alpha$ と $M$ 値は, 4 種 類の拘束圧下で行った少なくとも 4 本以上の試験結果か ら個々に求まる $\alpha, M$ 值をそれぞれ平均したものであ る.まず， $\alpha$ と $M$ の風化度依存性についてみると， $\alpha$ の值は，風化の進んだ試料ほど大きくなり， $M$ の值は 逆に小さくなる傾向を示している. また，これらの定数 に及ぼす含水比変動の影響は, $\alpha$ の值にはみられず, $M$ の値に現われている. 飽和試料の $M$ の值は, 自然含水 状態のそれに比べて $10 \%$ 程度小さくなっている.

Fig. 11 は, $M$ と圧縮定数の比 $C_{s} / C_{c}$ の関係を, 自然含 水比試料について示したものである. この図をみる限り では, $M$ と $C_{s} / C_{c}$ の間には, $C_{s} / C_{c}$ の増加に伴って
$M$ の値が減少するといった粘性土に対していわれてい るような特性はみられない。

軸差応力最大時におけるひずみ増分比 $(d v / d \varepsilon)_{f}$ と風 化度の関係，および試料 No. 8 の $(d v / d \varepsilon)_{f}$ と $\sigma_{3}$ の関係 を含水状態をパラメーターにとりそれぞれ Fig. 12, 13 に示した．まず，Fig. 12 をれば， $(d v / d \varepsilon)_{f}$ の值は， 拘束圧が大きくなるほど，また風化度が進んだものほよ゙ 小さくなる傾向が伺える，なお，広範な応力域における 乱さないまさ土の研究結果 ${ }^{21)} に$ 基づくと, 拘束圧増加お よび風化度増加に伴い, $(d v / d \varepsilon)_{f}$ の值はほぼ 0 に収束 するようである。

次に, Fig. 13 に示した試料 No. 8 について, 低圧力 下では飽和試料の $(d v / d \varepsilon)_{f}$ 值は自然含水比試料のもの より低いが，拘束圧の増大に伴って両者の値に明瞭な差 が現われなくなる。このような特性を粒子破砕とサク ションの観点から考えると以下のようになろう. まさ土 は, 飽和されることにより粒子破砕が促進され, またサ クション効果が消失すると考えるのが一般的である. し たがって, せん断中体積膨張を生じるような低い応力域 では, 水の存在によって生じる粒子破砕の体積変化特性 に与える影響が，サクション消失に伴うそれよりもはる かに大きいため, 結果的に飽和試料の方が低い $(d v / d \varepsilon)_{f}$ を示したと考える.しかし，拘束圧が増加す るのに伴い，1）水の存在による粒子破砕よりも，拘 束圧の増大に伴う粒子破砕の方が卓越し, その結果自然 含水比試料においてもかなりの粒子破砕が生じ，2） 自然含水比試料の飽和度が高くなり, 自然含水比試料の もっていたサクション効果が消失していくということ で，両者の $(d v / d \varepsilon)_{f}$ の差がなくなるものと考える.

\section{7. 乱さないまさ土の破壊時の強度特性}

\section{（1）せん断強度定数}

Fig. 14 は, 自然含水比試料における乱さないまさ土 の破壊時 (軸差応力最大時) の応力比 $\eta_{f}$ と風化度の関 係を拘束圧をパラメーターにして示したものである． $\eta_{f}$ 値は, 風化度の高い試料ほど, また拘束圧が大きいほ亡゙ 小さくなっている. しかし，拘束圧を約 $15 \mathrm{MPa}$ の応 力域まで拡張すると, 拘束圧増加に伴う $\eta_{s}$ 値の低下率 はしだいに娍少し一定值に収束する傾向にある211.

Fig. 15 は, 自然含水比試料の乱さないまさ土の破壊 包絡線を示したものである.すべての包絡線は明瞭な凸 型の曲線を呈している.このような傾向は, 密詰め砂に おいてもみられるが22), 乱さないまさ土は, きわめて破 砕性に富むため, 砂に比べて低い応力域から包絡線は非 線形性を呈する.なお, 吉中らは乱さないまさ土におい て応力約 $20 \mathrm{MPa}$ までは $\phi^{\prime}$ の減少がみられるが，この 応力以上になると $\phi^{\prime}$ は再び増加を始めるという結果を 


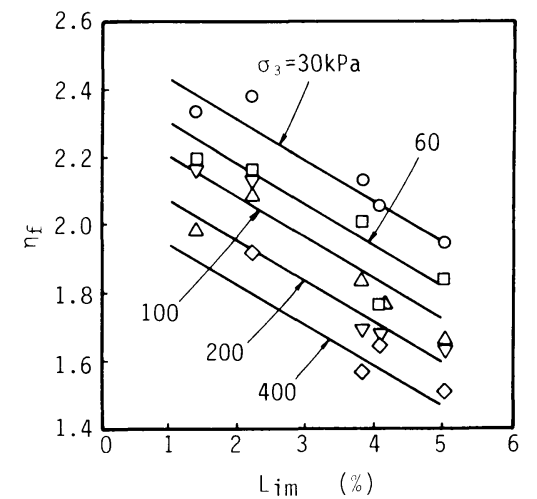

Fig. 14 Relation between $\eta_{s}$ and $L_{i m}$.

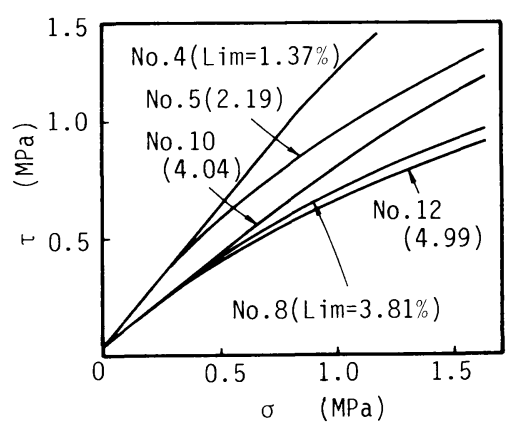

Fig. 15 Failure envelope curves of undisturbed specimens.

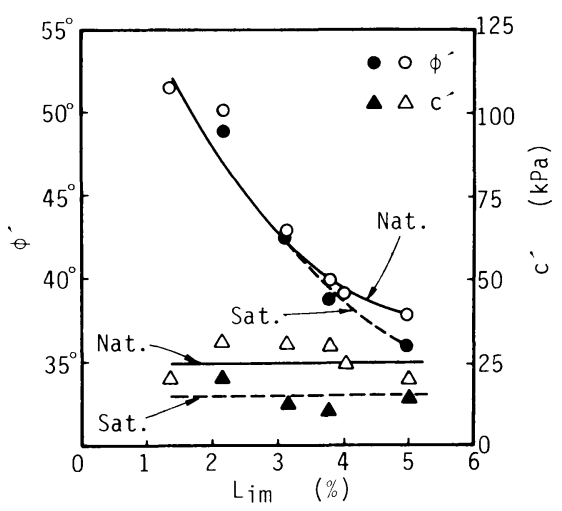

Fig. 16 Relation between shear constants $c^{\prime}, \phi^{\prime}$ at low stress region and $L_{i m}$

与えている11. ところで, 砂において測定される強度は, 純粋なすべり摩擦成分, 粒子破砕や粒子の再配列に起因 するダイレイタンシー成分および粒子破砕や粒子再配列 そのものによる成分の重ね合わせた結果として得られる という考えをLee and Seed ${ }^{23)}$ が示しており，このよう な考えが乱さないまさ土においても適用できると考える ならば，上述したような現象は起こり得る.

なお, 飽和した試料の破壊包絡線は, 見掛けの粘着力 が自然含水比試料のそれに比べて低下するものの, 包絡
線そのものは，ほぼ自然含水比試料の包絡線に平行で あった. Fig. 16 は, 自然含水比および飽和試料の破壊 包絡線をもとに, $\sigma<200 \mathrm{kPa}$ の応力域で決定した見掛 けの粘着力 $c^{\prime}$ および内部摩擦角 $\phi^{\prime}$ 之風化度の関係を表 わしたものである.この図から明らかなように, 自然含 水比状態の試料においては, 見掛けの粘着力が風化度に 関係なくほぼ同じであるのに対し， $\phi^{\prime}$ は風化度に依存 して, 約 35 度から 50 数度まで変化している. また, 試 料を飽和した場合, 浸水により比較的風化の進んだ式料 で若干の $\phi^{\prime}$ の低下がみられるものの, $\phi^{\prime} に は$ 浸水の影 響があまり現われないようである。しかしながら， $c^{\prime}$ については風化度に関係なく約 $50 \%$ の低下がみられ る.このような特性は, まさ土の地山斜面の安定性を検 討する際重要な知見であると考える.

\section{（2）破壊規 準}

前述したように, 乱さないまさ土の破壊包絡線は非線 形性を示すため, モール・クーロンの破壊規準の適用は 難しい，そこで，ここでは今回実験を行った応力域を対 象に, 破壊時の軸差応力 $q_{r}$ と平均主応力 $p_{f}$ および残 留時の軸差応力 $q_{r}$ と平均主応力 $p_{r}$ の関係を簡単に表 示することを試みた。

代表的な乱さない試料（No.4，10）の $q_{f}-p_{f}$ おび $q_{r}-p_{r}$ の関係を両対数座標上で示したのが, Fig. $17(\mathrm{a})$, (b) である. 一般に, $p$ の増加に伴って $q_{s}$ と $q_{r}$ の差は 消失していき, 最終的には $q_{s}$ 值は $q_{r}$ 值線上にのってく ることがわかる．そこで，まずすべての試料の $q_{r}$ と $p_{r}$ の関係を整理してみると, Fig. 18 に示したように, 風 化度に関係なくほぼ一本の直線で示されるという興味深 い結果が得られた。しかし， $q_{s}$ と $p_{f}$ の関係は応力ひず み曲線がひずみ硬化軟化型挙動を示す応力域でこの直線 から逸脱していることが, Fig.17(a)，(b) からわかる. また，全試料の $q_{s}$ と $p_{f}$ 関係も両対数上で直線関係に あり, かつこれらの勾配はほぼ等しいこともわかった. すなわち, Fig.17, 18 から, 破壊時においては,

$$
\frac{q_{f}}{p_{0}}=a\left(\frac{p_{f}}{p_{0}}\right)^{0.89}
$$

残留時においては,

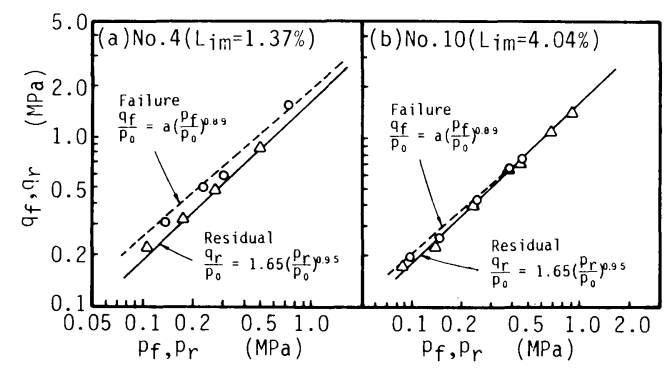

Fig. 17 Relation between $q$ and $p$ at failure and residual state. 


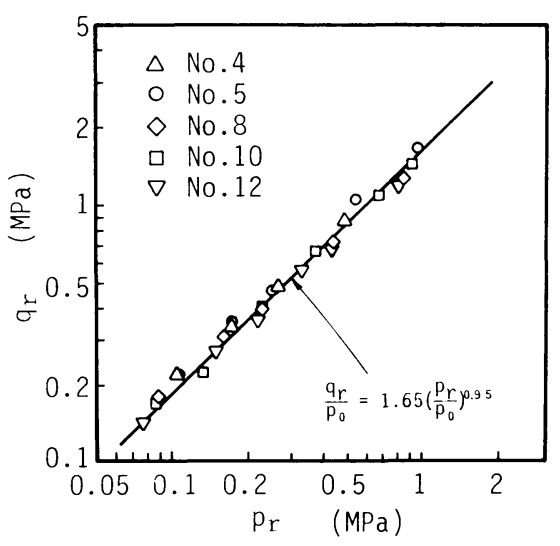

Fig. 18 Relation between $q_{r}$ and $p_{r}$.

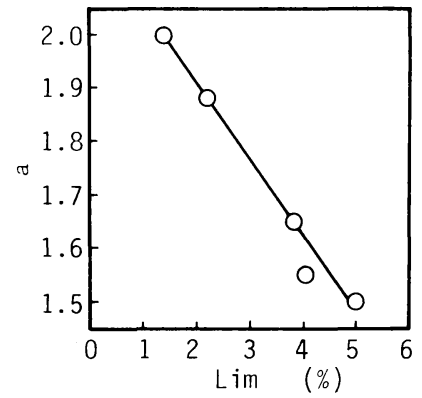

Fig. 19 Relation between constant $a$ and $L_{i m}$.

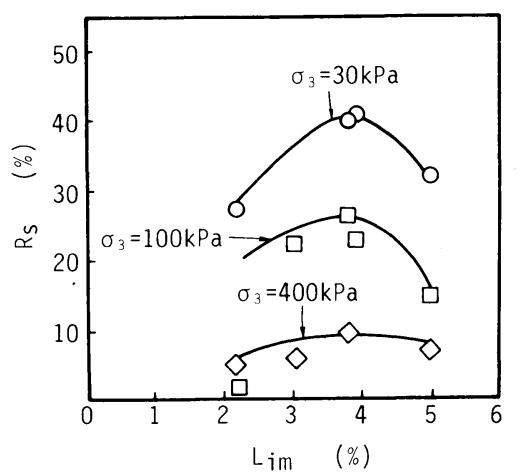

Fig. 20 Relation between the rate of strength decrease due to submergence and $L_{i m}$.

$$
\frac{q_{r}}{p_{0}}=1.65\left(\frac{p_{r}}{p_{0}}\right)^{0.95}
$$

で示される関係が得られる.ここで， $a$ は風化度に依存 する実験定数であり $p_{0}$ に対応する $q$ の值である.ここ では簡単のために， $p_{0}$ として単位応力 $(1 \mathrm{MPa})$ を選 んだ.このように, 破壊時の $q_{f}$ と $p_{f}$ の関係がベキ関 数型で表示されることは, 花崗岩や堆積軟岩においても 報告 ${ }^{24)}$,25)されており, 乱さないまさ土も岩石力学的な強 度特性も持ち合わせた材料であることを示唆するもので
ある・

次に, 式（3）の定数 $a$ は, 試料によって異なるの で $a$ と風化度の関係を調べたものが，Fig. 19 である. この図から， $a$ は風化度によく対応していることがわか る.

\section{（3）浸水による強度低下}

Fig. 20 は, 浸水による強度低下の割合と風化度の関 係を拘束圧をパラメーターにとり，軸差応力に着目して 示したものである．浸水による強度低下率 $R_{s}$ は次式で 定義した.

$$
R_{s}=\frac{\left(q_{\text {f.nat }}-q_{\text {f.sat }}\right)}{q_{\text {f.sat }}} \times 100
$$

ここで， $q_{\text {f.nat }}$ は自然含水比試料における最大軸差応力, $q_{\text {s.sat }}$ は飽和試料における最大軸差応力である.

図より, 各試料の式（5）で定義した強度低下率は, 拘束圧が低いほど著しく, また各拘束圧下における強度 低下率は， $L_{i m}$ が約 $4 \%$ すなわち適度に風化した試料 において最も顕著で, 強度低下率と風化度の関係は凸型 の曲線を示すことがわかった. この結果は, 実際適度に 風化したまさ土の自然斜面が豪雨時に頻繁に表層すべり

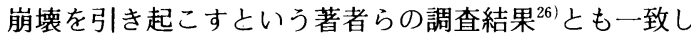
ている.

まさ土のような破砕性土の浸水による強度低下は, 主 として摩擦効果, セメンテーション効果, 粒子破砕およ びサクション効果の変化に起因していると著者の一人 が, 前に報告した ${ }^{16)}$. おそらく,このような種々の要因 の兼ね合せの結果として Fig. 20 に示した強度低下率と 風化度の関係が得られるものと考えられるが，これらの 要因が強度低下にそれぞれどのように寄与するのかを明 らかにしていくには，さらなる実験的な検討が必要であ る.

\section{8. 結 論}

乱さないまさ土の風化の程度を表わす指標として修正 強熱娍量を採用し, 新たに考案したコアビットを用いて 作成した乱さないまさ土供試体に対して, 実施した等方 圧縮および三軸圧縮試験結果に基づき主として自然含水 状態における圧縮 - せん断特性を風化度に着目して考察 した. 得られた結果を要約して以下に示す.

（1）等方圧縮下での間隙比変化は，粒子破砕と乱さ ないまさ土のもつ構造効果の消失によって規定される不 可逆的な塑性変形が大部分を占め, 弾性成分はごくわず かである。

（2）乱さないまさ土の応力・ひずみ挙動は, 風化度 亡拘束圧に依存し, ひずみ硬化軟化型からひずみ硬化型 の特性を示す.

（３）乱さないまさ土と乱したまさ土の力学的特性の 
相違は，低応力域において顕著にみられるが，拘束圧の 増加とともにその相違は消失していく．また，乱さない まさ土は, せん断中にかなりの粒子破砕を生じ，力学的 性質に大きな影響を及ぼしている。

（4）ストレス・ダイレイタンシー関係は，風化度や 含水状態によらず, 式 $(2$ ) で表示できるが, 式中の定 数 $\alpha$ は風化度に, $M$ は風化度と含水状態に依存する。

（５）破壊および残留強度と平均主応力の関係は，風 化度を考虑したべキ関数で表示できる。

（6）低圧域におけるせん断強度定数 $\phi^{\prime}$ は, 風化度 の増大とともに低下するが，見掛けの粘着力 $c^{\prime}$ には， 風化度依存性はさほどみられない，また，かなり風化し た試料を除き，浸水による $\phi^{\prime}$ の低下はみられないが, $c^{\prime}$ は風化度に関係なく約 $50 \%$ 低下する。

（7）乱さないまさ土の浸水による強度低下率は, 拘 束圧が低いほど著しい。また，それは，風化度にも依存 しており，適度に風化したまさ土（ $\left.L_{i m}=4 \%\right)$ におい て最も著しい低下を生じる.

最後に，本研究を行うにあたり，試料の一部採取で協 カしていただいた復建調査設計（株）の福田直三博士， 実験で協力を受けた浅上洋一氏 (現，宇部興産)，佐藤 研一氏 (現, 九州大学大学院), 松本清治郎氏（現, 名 古屋大学大学院）および, 試験機の改良之試料の採取で 多大の労力をわずらわせた山口大学技官 山本修三氏に 感謝の意を表する.

\section{参考 文 献}

1) Yoshinaka, R. and Onodera, T.F. : Undisturbed sam pling of decomposed granite soil and its mechanical properties, Proc. 9 th ICSMFE, Special Session 2, pp. 97 102, 1977.

2）柴田 徹・清水正喜・都司 尚：不摫乱マサ土の三軸強 度・変形特性, 第 17 回土質工学研究発表会講演集, pp. $465 \sim 468,1982$.

3）西田一彦・青山千彰：物理強度特性からみた乱さないま さ土の分類, 土木学会論文集, No. 352, pp. 159 168, 1984.

4）八木則男・矢田部龍一：不摫乱まさ土のせん断特性と微 視的考察, 土木学会論文集, No. 364, pp. 133 141, 1985.

5）村田秀一・安福規之・浅上洋一・大西禎行：不摫乱まさ 土の供試体作成方法の確立およびそのせん断特性, 第 20 回土質工学研究発表会講演集, pp. 489 490, 1985.

6）村田秀一・安福規之・浅上洋一：風化度の異なる乱さな いまさ土の圧縮・せん断特性, 第 21 回土質工学研究発表 会講演集, pp. 479 490, 1986.

7) 西田一彦・青山千彰：乱さないまさ土のせん断強度特性, 土と基礎, Vol.29, No.6, pp. 35 40, 1981.

8）村田秀一・安福規之・山本修三・浅上洋一：不靦乱まさ 土供試体の作成方法とその力学特性, 土質工学会昭和 60
年度サンプリングシンポジウム発表論文集, pp. $81 \sim 88$, 1985.

9）村田秀一・安福規之・浅上洋一・松本清治郎：凍結法に より成形された乱さないまさ土供試体の乱れの判定, 第 38 回土木学会中国四国支部研究発表会概要集, pp. 217 $218,1986$.

10）八木則男・矢田部龍一：室内試験のあれこれ，乱さない まさ土供試体の作成法，土と基礎，Vol. 31，pp. 62 63, 1983.

11）松尾新一郎：まさ土の特性と問題点, 土と基礎, Vol. 23, No. 2, pp. 1 8, 1975 .

12）土質工学会編：風化花崗岩とまさ土の工学的特性とその 応用, pp. 175 183, 1979 .

13）高橋 悟・田中弥寿男：まさ土の風化とその判定法につ いて, 地盤と建設, Vol. 1, No. 1, pp. 1 8, 1983.

14）西田一彦・佐々木清一・久保井利雄：まさ土の非晶質物 質とその特性について, 土質工学会論文報告集, Vol.24, No. 2, pp. $180 \sim 190,1984$.

15）村田秀一・安福規之・山本修三：まさ土の圧縮・せん断 特性と風化度の関係, 地盤と建設, Vol. 3, No. 1, pp. 11 $\sim 19,1985$.

16）三浦哲彦・村田秀一・原田 敦：含水比変動に伴なう破 砕性土のせん断特性変化, 土木学会論文報告集, No. 336, pp. 105 118, 1977.

17）三浦哲彦・山内豊聡：砂のせん断特性に及ぼす粒子破砕 の影響, 土木学会論文報告集, No. 260, pp. 109 118, 1977.

18）三浦哲彦・村田秀一・安福規之：粒状土の応力・ひずみ 特性（その1), 材料定数の粒子破砕依存性, 第 20 回土 質工学研究発表会講演集, pp. 341 342, 1985.

19）土質工学会編：土質試験法, pp. 668～693， 1979.

20) Haruyama, M. and Kitamura, R. : Anisotropic deformation-strength properties of soft sedimentary rock "Shirasu" originated from pyroclastic flows, Soils and Foundations, Vol.24, No.4, pp. 84 94, 1984.

21）大西禎行：不摫乱まさ土の供試体作成方法とその強度特 性, 山口大学卒業論文, 1985 .

22) Vesic, A. S. and Clough, G.W. : Behavior of granular materials under high stress, Proc. ASCE, Vol.94, SM 3, pp. 661 688, 1968.

23) Lee, K. L. and Seed, H. B. : Drained strength characteristics of sand, Proc. ASCE, Vol.93, SM 6, pp.117 139, 1967.

24) Yoshinaka, R. and Yamabe, T. : Strength criterion of rocks, Soils and Foundations, Vol.20, No.4, pp.113 $126,1980$.

25）足立紀尚・小川豊和：堆積軟岩の力学特性と破壊規準, 土木学会論文報告集, No. 295, pp. 51 63, 1980.

26）大原資生 - 村田秀一・松田 博 - 安福規之：昭和 60 年度 6 月山口県西部地区の豪雨災害の調查研究, 地盤災害特 性の調査, 文部省科学研究費自然災害研究突発災害研究 成果, No. B-60-2, pp. 47 61, 1986.

（1986.8.1 • 受付） 